\title{
Landscape Economic Attractiveness: An Integrated Methodology for Exploring the Rural Landscapes in Piedmont (Italy)
}

\author{
Vanessa Assumma 1,*(D), Marta Bottero ${ }^{1}(\mathbb{D})$ and Roberto Monaco ${ }^{2}$ \\ 1 Interuniversity Department of Urban and Regional Studies and Planning, Polytechnic of Turin, \\ Viale Mattioli 39, 10125 Turin, Italy \\ 2 Former Full Professor, Politecnico di Torino, 10129 Torino, Italy \\ * Correspondence: vanessa.assumma@polito.it
}

Received: 13 May 2019; Accepted: 25 June 2019; Published: 28 June 2019

check for updates

\begin{abstract}
The present paper focuses on an integrated evaluation methodology aimed at measuring the attractiveness of rural landscapes. The landscapes under observation are two exceptional contexts in Piedmont (Italy): The Moraine Amphitheatre of Ivrea and the vineyard landscape of Langhe, Roero and Monferrato, which have recently been included in the UNESCO World Heritage List. The proposed investigation tool consists of the use of a system of landscape indicators, from which a synthetic index called the landscape economic attractiveness index has been obtained, and the integration of the results in a dynamic model, considering the synthetic index as a factor of people mobility in a multi-pole system. This integrated approach aims at supporting the decision-making process in the definition and orientation of landscape and territorial transformation policies, respecting the landscape components.
\end{abstract}

Keywords: economic evaluation; landscape policies; landscape economics; indicators; dynamic model; scenario analysis

\section{Introduction}

The European Landscape Convention (ELC) [1] defined landscape as "an area, as perceived by people, whose characters are the result of the action and interaction of natural and/or human factors". In this way, the ELC highlighted the high complexity of landscape [2] and encouraged the adoption of a holistic approach to evaluate the various dimensions of landscape, especially the economic dimension. The ELC underlined the need for integrated evaluation models to solve complex problems and define sustainable solutions [3], such as the increase of the economic attractiveness of a landscape. In fact, it is generally agreed that landscape has a multi-faceted economic nature that contributes to define its territorial identity [4].

There are certain functions and activities in a landscape that increase its value by generating benefits and satisfying people's needs. In this sense, the fundamental idea of the economic value of landscape is anthropogenic and it is represented by the possibility of maximizing the benefits delivered to people, thus increasing the life quality [4]. Accordingly, landscape is a scarce public good that is both non-excludable and non-rivalrous [5,6]. This means that landscape is an externality, as the result of both positive and negative effects generated by a user's activities of production or consumption from another user's activities, without a real monetary transaction to balance the costs and benefits generated by these effects in the market [7]. Considering the economic dimension of landscape, there is an evident need to detect specific evaluation tools able to assess the economic features of landscape and to effectively support the decision-making process in the definition of policies and actions in the 
field of landscape and territorial planning. In this sense, the Total Economic Value (TEV) represents the most used approach for evaluating the economic value of environmental goods, such as a landscape. Generally, the TEV paradigm considers the evaluation of an environmental good in terms of use value and non-use value [8]. Economists generally support the idea that TEV value may be divided into three values. Firstly, use value is generated by user interactions with the environment, which can be direct, if it concerns the use of primary resources (e.g., harvest, timber), or indirect, if this derives from the benefits delivered by the ecosystem services to users (e.g., carbon sequestration). Secondly, option value is considered when the user preserves the use of goods and services in the future. Lastly, non-use value, also known as existence value, refers to the benefits delivered to people from the existence of a certain good or service, even if they never will use that resource [9].

The present research proposes an integrated evaluation methodology for experts and technicians of landscape and territorial planning to support the definition of policies and design transformation scenarios aimed at valorizing landscape resources. This integrated evaluation methodology combines the use of a Multiple Criteria Decision Analysis (MCDA), in the form of a system of landscape economic indicators, and a dynamic model, that is a mathematical model of the Lotka-Volterra type [10-14]. The considered evaluation methodologies have been combined in order to predict future possible scenarios by integrating the synthetic index of landscape economic attractiveness, obtained by the considered system of indicators, into the dynamic model.

The paper proposes an application of this integrated evaluation model in two rural landscapes located in Northern Italy (Piedmont), which are the Moraine Amphitheatre of Ivrea (MAI) and the vineyard landscape of Langhe, Roero, and Monferrato (LRM). The functionality and utility of this methodology is reported.

\section{The Integrated Evaluation Methodology}

The proposed integrated evaluation methodology is organized according to a multi-phase structure. The first phase consists of the definition of a system of landscape economic indicators, according to the MCDA approach (Multiple Criteria Decision Analysis). The second phase consists of data collection and elaboration in order to populate a territorial dataset of the landscapes under investigation. In the same phase, the synthetic index of the economic attractiveness, called Landscape Economic Attractiveness index (LEA), is calculated. In the third phase, the synthetic index is integrated into a mathematical model of the Lotka-Volterra type, which consists of a system of differential equations that predicts future scenarios based on the trends of people mobility versus time. In the context of this research, landscape is intended as a multi-pole territorial system constituted by a number of urban centers that are linked by a regular road network. Each urban center interacts with the other centers and the nature of the interaction depends on the reciprocal distances and the values of economic attractiveness $[10,11]$.

The multi-methodological background of these two approaches will be illustrated in detail in the remaining part of this section.

\subsection{The System of Landscape Economic Indicators}

Systems of indicators constitute the most used evaluation tool to assess and monitor a landscape. Generally, an indicator is a parameter used to measure a certain phenomenon by providing information on its characteristics and on its global form [15]. Economic assessment experiences have been included in landscape research, with emphasis on the use of landscape economic indicators [5] because these provide a mean for measuring the value of landscape focusing on its utility or functionality for the people use [16]. As far as landscape economic indicators are considered, these can be referred to quantitative and/or qualitative economic evaluation methods. The quantitative economic evaluation methods (i.e., monetary approach) estimate the willingness to pay to use a landscape to be evaluated. Within this family of methods, it is possible to recall the Contingent Valuation method, the Choice Experiments technique $[17,18]$, the Stated Preferences methods $[19,20]$ or the Hedonic Pricing method [21,22]. 
The qualitative economic evaluation methods (i.e., non-monetary approach) is finalized to calculate an average score of landscape by considering a set of qualitative and quantitative criteria and including the opinion of experts and society in the evaluation [23]. Table 1 summarizes the main economic evaluation methodologies shared in literature for assessing a landscape.

Table 1. Economic evaluation methodologies: Monetary and non-monetary approaches (elaboration from Marangon and Tempesta, 2008).

\begin{tabular}{|c|c|c|c|c|}
\hline \multicolumn{4}{|c|}{ Economic Evaluation Methods } & Description \\
\hline \multicolumn{4}{|c|}{ Non-Monetary } & $\begin{array}{l}\text { Average Score of Landscape as a Whole or as a } \\
\text { Singular Element(s) }\end{array}$ \\
\hline \multirow{6}{*}{ Monetary } & \multirow{4}{*}{$\begin{array}{l}\text { Demand-based } \\
\text { (benefits) }\end{array}$} & \multirow{2}{*}{$\begin{array}{l}\text { Revealed } \\
\text { Preferences }\end{array}$} & Transport costs & $\begin{array}{l}\text { Recreational benefits per hectare of singular } \\
\text { element of landscape }\end{array}$ \\
\hline & & & Hedonic pricing & $\begin{array}{l}\text { Price change per square meter of a residential } \\
\text { building referred to the overall quality of } \\
\text { landscape or to the visibility of singular elements }\end{array}$ \\
\hline & & \multirow{2}{*}{$\begin{array}{l}\text { Established } \\
\text { Preferences }\end{array}$} & $\begin{array}{l}\text { Contingent } \\
\text { valuation }\end{array}$ & $\begin{array}{l}\text { Willingness to pay per hectare to maintain or } \\
\text { enhance the landscape as a whole }\end{array}$ \\
\hline & & & Choice experiment & $\begin{array}{l}\text { Willingness to pay per hectare for the singular } \\
\text { element of landscape }\end{array}$ \\
\hline & \multirow{2}{*}{ Offer based (costs) } & \multicolumn{2}{|c|}{ Opportunity cost } & $\begin{array}{l}\text { Reduction in income per hectare per increase } \\
\text { unit in the landscape quality }\end{array}$ \\
\hline & & \multicolumn{2}{|c|}{ Defensive expenditures } & $\begin{array}{l}\text { Costs of conservation of singular elements of } \\
\text { landscape as a whole }\end{array}$ \\
\hline
\end{tabular}

This research work chooses a non-monetary evaluation by employing a set of indicators that are finalized to evaluate the landscape economic attractiveness as it concerns its elements. As noticed by Gómez-Sal et al. (2013) [24], indicators are not a panacea and there is a need to research them with reference to their importance, structure, relations, and place them into a hierarchy. This allows the indicators system to be used for evaluating the territory under examination and to see how it addresses future possible scenarios. Therefore, we have structured the system of landscape economic indicators according to the Analytic Hierarchy Process (AHP) because it allows the evaluation of both qualitative and quantitative aspects of complex problems $[25,26]$. Therefore, we have defined the following elements: The goal, that is the assessment of the landscape economic attractiveness; the criteria which are represented by four economic categories and these are further subdivided into economic indicators; and the alternatives that correspond to a set of territorial clusters. The economic categories chosen for this evaluation represent the most important aspects that contribute to the economic attractiveness of a landscape and arise from the relevant literature in the domain of economic evaluation of landscape [27]: Agriculture (A), Tourism (T), Real estate market (R) and Forestry (F). The Agriculture category concerns the existing relations between agricultural landscapes and the economic system, considering rural employment and local investment [28,29]. The Tourism category aims at analyzing the role of landscape in attracting tourism flows [30]. As far as the Real estate category is considered, landscape and general natural amenities have a fundamental role in generating benefits on property values considering both buildings and agricultural fields [31]. All this research agrees in considering landscape as a positive externality that generates benefits on property values. Finally, the Forestry category represents the benefits delivered by forestry management and activities for local economic development.

Table 2 represents the system of landscape economic indicators employed in the present research. The landscape economic indicators are then aggregated following the subsequent levels of the hierarchy thus obtaining a synthetic index called LEA (Landscape Economic Attractiveness). 
Table 2. The system of landscape economic indicators (Elaboration from Assumma et al., 2016).

\begin{tabular}{|c|c|c|c|c|c|c|c|}
\hline \multicolumn{8}{|c|}{ The System of Landscape Economic Indicators } \\
\hline & griculture (A) & & Tourism (T) & Rea & Estate Market (R) & & orestry $(F)$ \\
\hline$x_{1}$ & $\begin{array}{l}\text { Agricultural } \\
\text { farms [No.] }\end{array}$ & $x_{6}$ & Tourism arrives [No.] & $x_{10}$ & $\begin{array}{c}\text { Real estate value } \\
{\left[€ / \mathrm{m}^{2}\right]}\end{array}$ & $x_{12}$ & $\begin{array}{l}\text { Forest surface } \\
\qquad\left(\mathrm{m}^{2}\right)\end{array}$ \\
\hline$x_{2}$ & Bio farms [No.] & $x_{7}$ & Tourism presences [No.] & $x_{11}$ & $\begin{array}{l}\text { Agricultural } \\
\text { value }[€ / \text { ha] }\end{array}$ & $x_{13}$ & $\begin{array}{l}\text { Forest farms } \\
\text { (No.) }\end{array}$ \\
\hline$x_{3}$ & $\begin{array}{c}\text { PDO/PGI farms * } \\
\text { [No.] }\end{array}$ & $x_{8}$ & $\begin{array}{c}\text { Accommodation } \\
\text { capacity-beds [No.] }\end{array}$ & & & & \\
\hline$x_{4}$ & $\begin{array}{c}\text { Agriculture } \\
\text { Workers [No.] }\end{array}$ & $x_{9}$ & $\begin{array}{l}\text { Accommodation capacity in } \\
\text { Farmhouses - beds [No.] }\end{array}$ & & & & \\
\hline$x_{5}$ & $\begin{array}{c}\text { Utilized } \\
\text { Agricultural } \\
\text { Surface }\left[\mathrm{m}^{2}\right]\end{array}$ & & & & & & \\
\hline
\end{tabular}

* $\mathrm{PDO} / \mathrm{PGI}$ are the farms that produce eno-gastronomic products certified as "Product of Denomination Origin" (PDO) and "Product of Geographical Indication" (PGI).

It can be observed that the LEA index is something different from other economic indices such as the Gross Domestic Product index (GDP). In fact, the GDP is a parameter for measuring the economic performance of a territory, without considering sustainability issues or quality of life. Many drawbacks and limitations have been recognized in using the GDP as a measure of the economic well-being of an area and so other aggregated sustainability measures have been proposed [32]. It has to be noticed that, compared to GDP, the LEA is a non-dimensional index that is constructed considering multidimensional indicators which contribute, at different degrees of importance, to the definition of the landscape value. In fact, while GDP can be useful in the tackling the specific problems of economic development in a region, the borders of landscape value are certainly vaster and a number of indicators is required. In this sense, indicators and composite indicators are increasingly recognized as a useful tool for policy making and public communication [33]. Following the latest initiatives in the context of suitability indicators frameworks, a number of components of a landscape (e.g., agriculture, tourism, real estate market and forestry) and the economic benefits that it provides to people, are included in this model. Municipal data have been collected and then organized in a system of territorial clusters (also known as Landscape Units), according to the territorial and landscape continuity of the considered Municipalities. As far as the LEA is considered, the purpose is to provide an integrated evaluation of the economic attractiveness of a landscape, focusing on the different benefits provided to people.

The subsequent phases provide the estimation of the landscape economic attractiveness, through normalization and aggregation formulas.

Normalization is employed to relate a certain numeric value $x_{i}$ with the maximum value $x_{i}^{\text {max }}$ recorded in the same category among clusters, whose result is a normalized indicator $I_{i}$. As shown in Equation (1), the normalization allows all indicators to be comparable in an interval between 0 and 1 .

$$
I_{i}=\frac{x_{i}}{x_{i}^{\max }}
$$

Weighting is an important step to know the importance of the different evaluated elements. It is important to notice that the set of weights used in this evaluation has been determined by the utilization of the analytic hierarchy process [25] with a panel of experts. In this case, it was presented to a panel of experts in agriculture, tourism, real estate, and forestry fields, the importance of the economic elements of landscape $[11,34]$ using the pairwise comparison method. The experts expressed a value through the Saaty's scale values from 1 to 9 , where 1 means same importance and 9 means extremely strong importance. Subsequently, the values have been converted into a set of weights through the software Expert Choice. Table 3 reports the set of weights obtained. 
Table 3. The set of weights to assess the importance of the landscape economic indicators.

\begin{tabular}{|c|c|c|c|c|c|c|c|}
\hline \multicolumn{8}{|c|}{ Set of weights-Criteria } \\
\hline \multicolumn{2}{|c|}{ Agriculture (A) } & \multicolumn{2}{|c|}{ Tourism $(\mathrm{T})$} & \multicolumn{2}{|c|}{ Real Estate Market (R) } & \multicolumn{2}{|r|}{ Forestry $(\mathrm{F})$} \\
\hline \multicolumn{2}{|c|}{$\mathrm{y}_{1}=0.570$} & \multicolumn{2}{|c|}{$\mathrm{y}_{2}=0.168$} & \multicolumn{2}{|c|}{$\mathrm{y}_{3}=0.075$} & \multicolumn{2}{|r|}{$\mathrm{y}_{4}=0.187$} \\
\hline \multicolumn{8}{|c|}{ Set of weights-Sub-criteria } \\
\hline \multicolumn{2}{|c|}{ Agriculture (A) } & \multicolumn{2}{|c|}{ Tourism (T) } & \multicolumn{2}{|c|}{ Real Estate Market (R) } & \multicolumn{2}{|r|}{ Forestry $(\mathrm{F})$} \\
\hline $\mathrm{x}_{1}$ & $\mathrm{w}_{1}=0.049$ & $x_{6}$ & $\mathrm{w}_{6}=0.402$ & $\mathrm{x}_{10}$ & $\mathrm{w}_{10}=0.400$ & $\mathrm{x}_{12}$ & $\mathrm{w}_{12}=0.250$ \\
\hline$x_{2}$ & $\mathrm{w}_{2}=0.245$ & $x_{7}$ & $\mathrm{w}_{7}=0.281$ & $x_{11}$ & $\mathrm{w}_{11}=0.600$ & $x_{13}$ & $\mathrm{w}_{13}=0.075$ \\
\hline$x_{3}$ & $\mathrm{w}_{3}=0.129$ & $\mathrm{x}_{8}$ & $\mathrm{w}_{8}=0.064$ & & & & \\
\hline $\mathrm{x}_{4}$ & $\mathrm{w}_{4}=0.401$ & $\mathrm{x}_{9}$ & $\mathrm{w}_{9}=0.253$ & & & & \\
\hline$x_{5}$ & $\mathrm{w}_{5}=0.176$ & & & & & & \\
\hline
\end{tabular}

Once the set of weights is obtained, it is possible to aggregate the sub-criteria in partial indices by calculating the weighted average sum, as shown in Equations (2) and (3).

$$
\begin{gathered}
A=\sum_{i=1}^{5} w_{i} I_{i}, \quad \sum_{i=1}^{5} w_{i}=1 \\
T=\sum_{i=1}^{4} w_{i} I_{i}, \quad \sum_{i=1}^{4} w_{i}=1 \\
R=w_{10} I_{10}+w_{11} I_{11}, w_{10}+w_{11}=1 \\
F=w_{12} I_{12}+w_{13} I_{13}, w_{12}+w_{13}=1
\end{gathered}
$$

Finally, a synthetic index named the Landscape Economic Attractiveness index is obtained through the aggregation of partial indices using the following formula:

$$
L E A=y_{1} A+y_{2} T+y_{3} R+y_{4}, \sum_{k=1}^{4} y_{k}=1
$$

This synthetic index is a non-dimensional value between zero and one, where zero means a lesser economic attractiveness, and one is the maximum economic attractiveness in the landscape under investigation.

Finally, the LEA indices are related to the clusters surface $\left(\mathrm{Km}^{2}\right)$, thus obtaining the Specific Landscape Economic Attractiveness index (SLEA).

$$
S L E A=\frac{L E A}{\text { Cluster surface in } \mathrm{Km}^{2}}
$$

In order to better differentiate LEA and SLEA indices, the numerical figures were normalized, translating the original scores into the $0-1$ scale and awarding 1 the maximum value within the considered set. The LEA indices will be used in such parameter within the dynamic model. In the following paragraph, the relation between landscape evaluation and mathematical modeling is examined.

\subsection{The Dynamic Model}

In order to test the influence of the economic attractiveness on the possible people mobility throughout the landscape under observation, a suitable mathematical model has been used. Such a model consists of a system of differential equations, used in the 1980s [10] to study the city and its issues, according to the idea that the population changes depending on both the environment and 
mobility, which is the level of proximity of a generic $i$ center of the neighboring cities, and the economic attractiveness value, represented by their own economic, social, and cultural components. The present survey is about the possible dynamic fluxes of population, moving permanently for a change of residence. Such a model [35] has been recently adapted for a problem concerning gross leasable areas in the valley communities of the autonomous province of Trento in Italy [36].

In this study, people mobility is closely related to landscape economic attractiveness, as a high LEA value in a given center implies a high number of people living in the neighboring centers who will be willing to move to that center.

Given a system composed of a number of urban centers, linked by a regular road network, whose reciprocal distances $\left(d_{i j}\right)$ and the attractiveness coefficients (respectively, $A_{i}$ that is the attractiveness exerted by the $i$ center on its own population, and $A_{i j}$, the attractiveness of the $i$ center as perceived by the populations of the other $j$ centers) are known, it is possible to formulate a system of differential equations which may be viewed as a special type of the cooperative Lotka-Volterra system $[35,37]$.

The state variable of the mathematical model is the number of residents $p_{i}$ of each cluster. The mathematical system which will be employed for the simulations proposed further on is then given by

$$
p^{\prime}{ }_{i}=A_{i} p_{i}\left(1-\frac{p_{i}}{s_{i}}\right)+\sum_{\substack{j=1 \\ j \neq i}}^{N} A_{i j p_{j}}
$$

The variation of population ( $p^{\prime}{ }_{i}$ is the time derivative) of the $i$ cluster is determined by the two terms of the second member of Equation (5). The first term is of the logistic type and depends on the carrying capacity $1 / s_{i}, s_{i}$ being a suitable threshold which takes into account that the $i$ cluster may suffer if it is overcrowded, while the second member depends on the attractiveness parameters $A_{i j}$. According to the properties of the cooperative Lotka-Volterra type equations, the differential system has always at least one stable equilibrium solution [38].

As it concerns the coefficients $A_{i j}$, they have been calculated according to the following formula:

$$
A_{i j}=B_{i j}\left(1-\frac{d_{i j}}{d_{M}}\right)^{2} \quad B_{i j}=\frac{A_{i}}{A_{j}}
$$

where $d_{M}$ is the maximum value of the distances $d_{i j}$ in the road network for any value of $i$ and $j$. Observe that the attractiveness $B_{i j}$ of the $i$ cluster perceived by the other ones depends directly on $A_{i}$ and is inverse proportional to $A_{j}$ so that the relative strength of the cluster $i$ is conditioned by the attractiveness of the cluster $j$.

In conclusion, the dynamics of the model depends on the attractiveness coefficients of the clusters, on their threshold values, and on the reciprocal distances among the clusters themselves, so that the model expresses the limitation of people mobility in the territory. As it will be shown in the simulations, the attractiveness coefficients characterize the trends of fluxes during the transient times of simulation, while the threshold values and the reciprocal distances between clusters determine the repartition of the population values among the clusters themselves in a standard condition.

\section{Case Studies}

\subsection{The Moraine Amphitheatre of Ivrea}

The Moraine Amphitheatre of Ivrea (MAI) is one of the best-preserved geological contexts in the world. It was generated by the retreat of the Balteo Glacier, and it is situated in the northeast of Piedmont. The term "amphitheater" is used to define this landscape due to the peculiar shape of 
the moraine reliefs that surround the Canavese valley. It covers a surface of over 50,000 hectares for 80 Municipalities and touches the provinces of Turin, Biella, and Vercelli.

The Moraine Amphitheatre of Ivrea stands out for the peculiar tangible and intangible resources such as the historic architectures and the industrial heritage of Olivetti enterprise, the vineyard terraces, the Serra di Ivrea, the Five Lakes, the historic Carnival of Ivrea, the Via Francigena, and many other. The city of Ivrea has recently been included in the World Heritage List (WHL) of United Nations Educational, Scientific and Cultural Organization (UNESCO) as "Industrial City of the 20th century" (2018). As a matter of fact, until the mid-1990's Ivrea was the home of Olivetti, one of the most important Italian industrial enterprises, able to generate innovation and social capital.

For the purpose of the present evaluation, the Municipalities of the MAI landscape have been grouped into 8 territorial clusters. The Regional Landscape Plan of Piedmont submits the region to specific policies of conservation and valorization and also defines the boundaries of the "Ambits of Landscape" and the "Units of Landscape" in order to ensure the landscape connectivity. Specifically, a number of Units of Landscape (or clusters) constitutes a given Landscape Ambit and the administrative boundaries may be contained totally or partially within it. The Municipalities of the MAI landscape are mainly contained in the Landscape Ambit No. 28 "Eporediese" (see Figure 1b). As shown in Figure 1, the clusters are represented by the Municipality with the highest number of inhabitants, namely Cluster 1 (Ivrea), Cluster 2 (Lessolo), Cluster 3 (Borgofranco d'Ivrea), Cluster 4 (Bollengo), Cluster 5 (Moncrivello), Cluster 6 (Pavone Canavese), Cluster 7 (Caluso), Cluster 8 (Castellamonte).

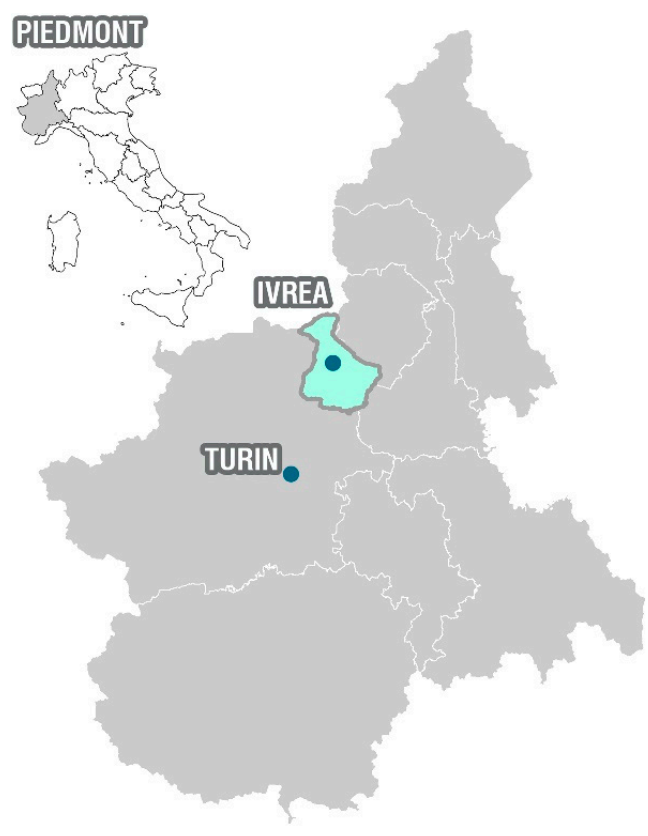

(a)

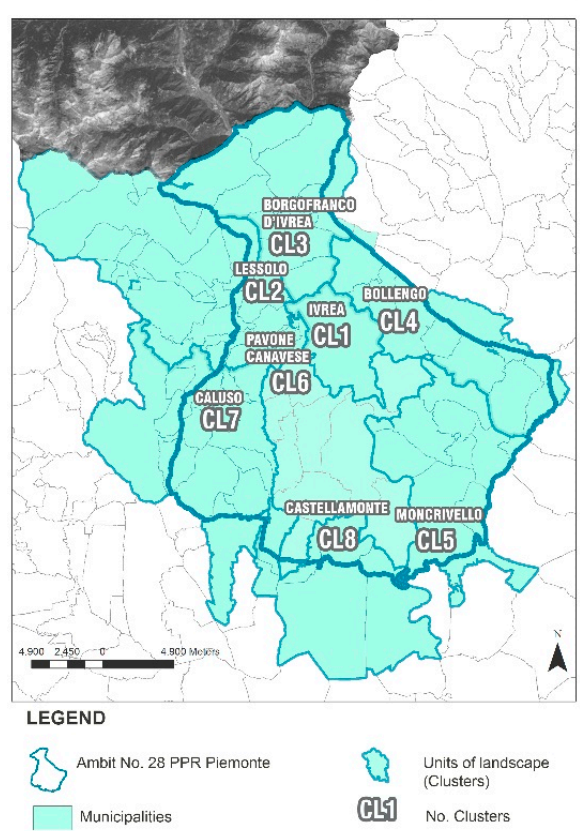

(b)

Figure 1. Territorial localization of the MAI (Moraine Amphitheatre of Ivrea) landscape (a) and the system of territorial clusters of the MAI landscape (b).

\subsection{The Vineyard Landscape of Langhe, Roero and Monferrato}

The vineyard landscape of Langhe, Roero and Monferrato (LRM) is a famous wine region modeled for centuries by the local communities and dedicated to the cultivation and production of excellent Italian wines, for which there is a high demand all over the world. Situated in southern Piedmont and adjoining the Liguria Apennines, the vineyard landscape covers a surface of over 80,000 hectares for 101 Municipalities belonging to the provinces of Alessandria, Asti, and Cuneo. The vineyard 
landscape of Piedmont became a UNESCO site in 2014 for its natural and cultural components. The perimeter of the UNESCO site is structured into six core zones and two buffer zones. The core zones preserve the Outstanding Universal Value (OUV), whereas the buffer zones protect the core zones and, at the same time, these assure the connection between the elements of the wine-making process [39]. As already specified in Section 3.1, the role of the Units of Landscape is very important for the landscape connectivity and conservation. In fact, the boundaries of this UNESCO site were designed in conformity of the Units of Landscape [40]. These facilitate the integration between several elements: From cultivation to production, from wine conservation to the commercialization of the final product.

For the present evaluation, the Municipalities of the LRM landscape have been organized into 8 clusters that are included in the core zones and the buffer zones of the UNESCO site (Figure 2): Cluster 1 (Diano d'Alba), Cluster 2 (Grinzane Cavour), Cluster 3 (Neive), Cluster 4 (Nizza Monferrato), Cluster 5 (Canelli), Cluster 6 (Rosignano Monferrato), Cluster 7 (Asti), and Cluster 8 (Casale Monferrato).

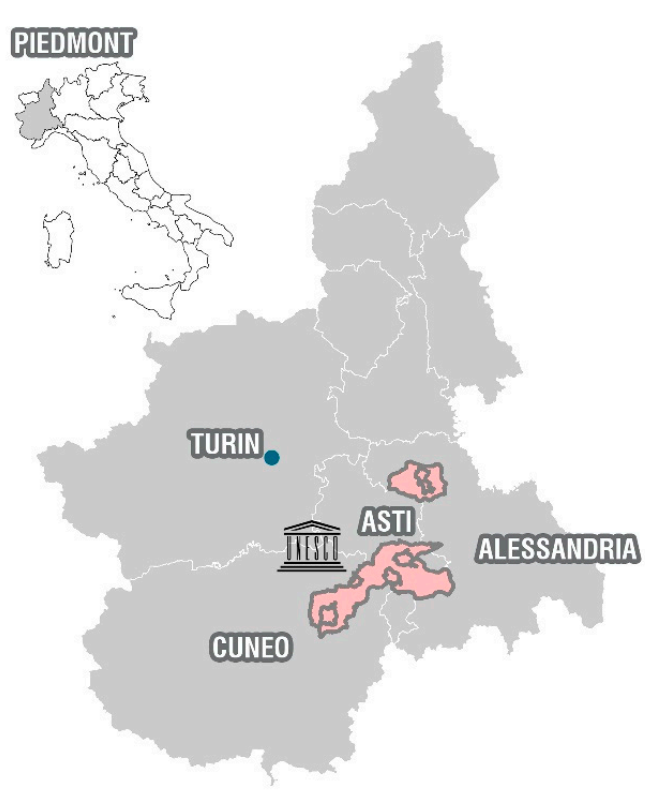

(a)

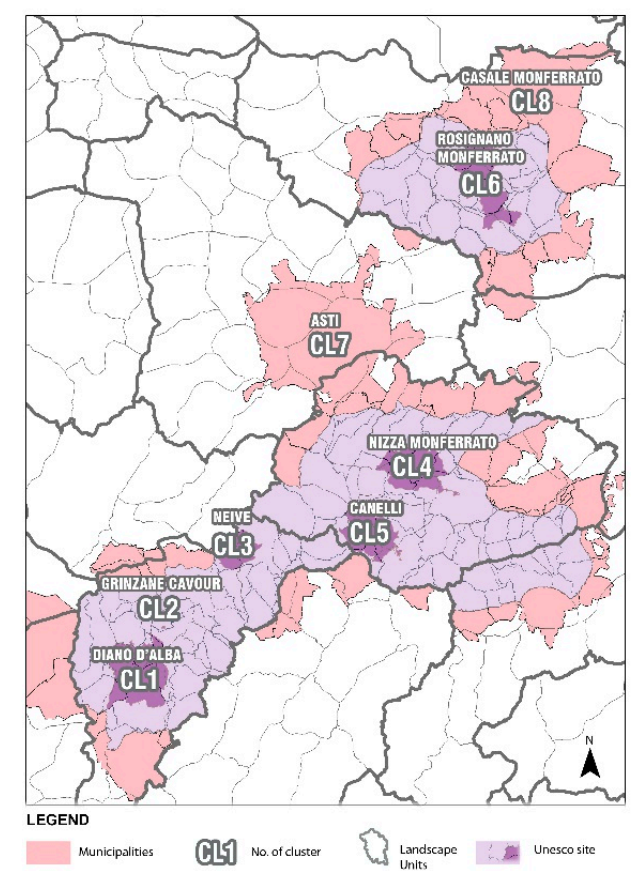

(b)

Figure 2. Territorial localization of the LRM landscape (a) and system of territorial clusters of the vineyard landscape are included the core zones and the buffer zones of the UNESCO site (b).

\section{Results}

Following the methodology described in Section 2.1, the LEA and SLEA indices have been calculated for the two landscapes under investigation.

\subsection{Results for the Moraine Amphitheatre of Ivrea}

Figure 3 represents the results of the synthetic indices for the MAI landscape. The output of the normalization and aggregation operations show the highest values of attractiveness 1 for the cluster of Bollengo (CL4) and the cluster of Castellamonte (CL8). The lowest value is equal to 0.320 for CL1 (cluster of Ivrea). The rest of clusters show values between 0.540 and 0.960 .

Moreover, as it can be seen in the first diagram (see Figure 3a), the agriculture index (A) shows a major influence in clusters $4,7,8$ equal to 0.300 . The tourism index ( $\mathrm{T}$ ) reaches the maximum value in CL5, equal to 0.180 , because of the touristic tendency. The real estate index (R) has a major influence in clusters 2, 5, 8 (values ranged between 0.180 and 0.070) and lowest values in clusters 3 and 4 (equal 
to 0.040 ); the forestry index $(\mathrm{F})$ is the most important in these clusters (values ranged between 0.150 and 0.180 ).

The cluster of Ivrea (CL1) is a peculiar cluster because is the most important Municipality in the MAI landscape, being the center of the Canavese valley. Considering this peculiarity, a low LEA index was not expected. This value is due to the limited presence of agricultural and forestry activities and the industrial attitude of Ivrea. For this reason, the agricultural and forestry indicators are very low, showing thus a poor performance in terms of total LEA index.

With reference to the SLEA indices (Figure $3 b$ ), the highest value is 1 for the cluster of Bollengo (CL4). The minimum SLEA index is 0.430 for the cluster of Lessolo (CL2), whereas the remaining clusters vary between 0.530 and 0.890 .

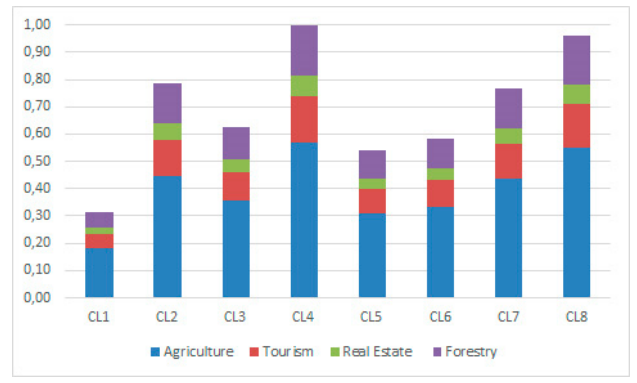

(a)

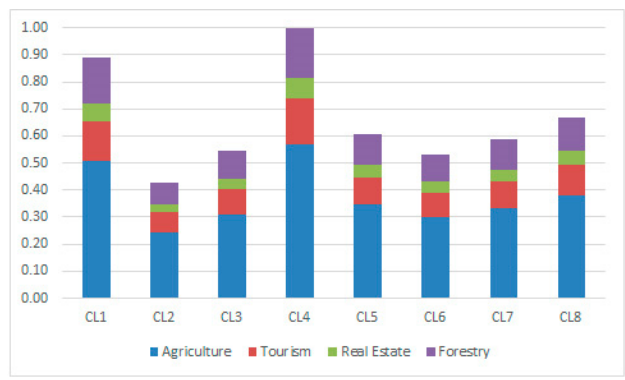

(b)

Figure 3. Landscape Economic Attractiveness index (LEA) (a) and Specific Landscape Economic Attractiveness (SLEA) (b) for the MAI landscape.

\subsection{Results for the Vineyard Landscape of Langhe, Roero and Monferrato}

Figure 4 presents the results of the synthetic indices for the LRM landscape. As it is possible to see (Figure 4a), the maximum LEA index is reached by the cluster of Asti (CL8), equal to 1, because of the multitude of Municipalities constituting the cluster, whereas the lowest value is recorded by the cluster of Grinzane Cavour (CL2), equal to 0.005. The remaining clusters are ranged between 0.060 and 0.340 . The Agriculture category (A) dominates in all clusters, because the UNESCO site is characterized by many agricultural activities and little settlements; particularly, the highest agricultural indices are recorded in CL7 and CL1, equal to 0.570 and 0.190. The couples of clusters CL3-CL6 and CL4-CL5 and the CL8 (CL8) show similar values, included in a range between 0.030-0.040 and 0.080-0.090. The tourism category $(\mathrm{T})$ shows higher values, since several historic and cultural resources favor attractiveness. The highest values are in CL7 and CL1, equal to 0.170 and 0.060 , whereas the values of the remaining clusters are ranged between 0 and 0.030 . As it concerns the categories of real estate (R) and the forestry (F), the clusters CL7 and CL1 show the highest values, respectively 0.080 and 0.030 for real estate and 0.190 and 0.060 for forestry. The LEA indices have been normalized and then related to the territorial surface $\left(\mathrm{Km}^{2}\right)$, obtaining a specific landscape economic attractiveness index (SLEA) (Figure 4b). The SLEA has been also normalized; the clusters CL1 and CL5 result the most attractive clusters, equal to 1 and 0.910 . 


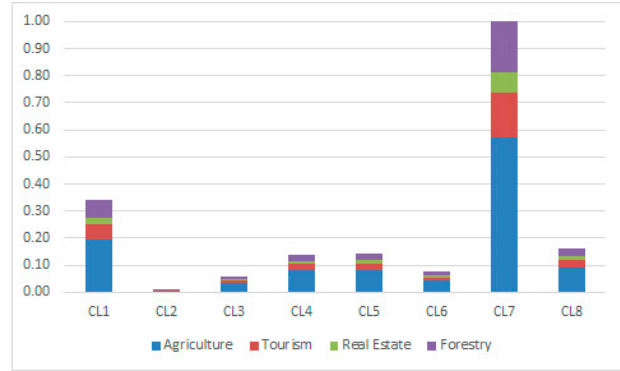

(a)

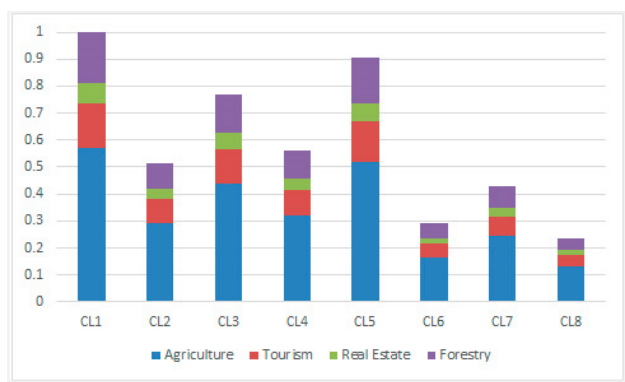

(b)

Figure 4. Landscape economic attractiveness index (LEA) (a) and specific landscape economic attractiveness index (SLEA) (b) for the LRM landscape (elaboration from Assumma et al., 2019).

\section{Integration of Landscape Economic Attractiveness Index into the Dynamic Model}

In this section, some simulations are proposed using the dynamic model in order to investigate a possible mobility of residents inside the two territorial environments being the purpose of the research. The aim of this integration is the definition of territorial transformation scenarios, considering that the landscape value, which is expressed by the LEA index, can exert attractiveness for people movements. This model assumes the higher LEA of a cluster, the higher value will be the number of residents in the considered system who would be willing to move in that cluster. Therefore, the data obtained for the two landscape contexts have been then inserted into the dynamic model. As it concerns the attractiveness coefficients $A_{i}$, we have assumed that they are given by the LEA indices for each cluster, renormalized to the maximum value exhibited in Figures 3 and 4. The calculation of the thresholds $s_{i}$ has been determined by multiplying the areas of the clusters (see Tables 4 and 5) by the value 180, which is indicated in northern Italy as the conventional value of residents per $\mathrm{Km}^{2}$, assuring a comfortable and sustainable standard of urbanization [32]. The maximum distance $d_{M}$ recorded for the vineyard landscape of Langhe, Roero and Monferrato is the one of 56,8 km from Grinzane Cavour (CL2) to Rosignano Monferrato (CL6); while the $d_{M}$ in the Moraine Amphitheatre of Ivrea is the one of $25.98 \mathrm{~km}$ from Borgofranco d'Ivrea (CL3) to Caluso (CL7) (see also [10]).

Table 4. Parameters of the dynamic model for the MAI landscape.

\begin{tabular}{lcccc}
\hline & Clusters & Population & Surface $\left(\mathrm{Km}^{2}\right)$ & LEA $\left(A_{\boldsymbol{i}}\right)$ \\
\hline CL1 & Ivrea & 23.606 & 30.11 & 0.316 \\
CL2 & Lessolo & 7772 & 154.64 & 0.785 \\
CL3 & Borgofranco & 12.440 & 97.11 & 0.625 \\
CL4 & Bollengo & 12.251 & 84.62 & 1.000 \\
CL5 & Moncrivello & 6681 & 75.48 & 0.540 \\
CL6 & Pavone Canavese & 23.414 & 93.23 & 0.583 \\
CL7 & Caluso & 16.744 & 110.65 & 0.766 \\
CL8 & Castellamonte & 21.425 & 121.84 & 0.962 \\
\hline
\end{tabular}

Table 5. Parameters of the dynamic model for the LRM landscape (core and buffer zones).

\begin{tabular}{lcccc}
\hline & Clusters & Population & Surface $\left(\mathbf{K m}^{2}\right)$ & LEA $\left(A_{i}\right)$ \\
\hline CL1 & Diano d'Alba & 11.435 & 133.38 & 0.340 \\
CL2 & Grinzane Cavour & 2010 & 3.81 & 0.005 \\
CL3 & Neive & 4101 & 29.06 & 0.057 \\
CL4 & Nizza Monferrato & 17.632 & 97.71 & 0.140 \\
CL5 & Canelli & 15.906 & 62.72 & 0.145 \\
CL6 & Rosignano Monferrato & 6754 & 101.23 & 0.075 \\
CL7 & Asti & 199.328 & 919 & 1.000 \\
CL8 & Casale Monferrato & 48.374 & 272.16 & 0.163 \\
\hline
\end{tabular}


As discussed in Section 2.2, this type of dynamical model admits at least one stable equilibrium solution. Actually, if there is only one stable equilibrium solution, then the system will reach such a solution straightforwardly, not necessarily with a monotone behavior. Conversely, if the (stable or unstable) equilibria are more than one, then the system can behave as follows: First, by approaching an unstable equilibrium and remaining there for a certain time; then going asymptotically to a stable equilibrium. Generally, such transient behavior is dominated by the attractiveness effect, while the asymptotic trend is dominated by the values of the thresholds $s_{i}$.

In the case studies shown in the next sections, the Moraine Amphitheatre of Ivrea presents such a transient behavior, whereas the vineyard landscape of Langhe, Roero and Monferrato shows a straightforward trend to the stable equilibrium without any transient settlement to another (unstable) equilibrium. Tables 4-6 show the values of the parameters for the application of the dynamic model to the landscapes under investigation.

Table 6. Parameters for the dynamic model for the LRM landscape (core zones only).

\begin{tabular}{lcccc}
\hline & Clusters & Population & Surface $\left(\mathrm{Km}^{2}\right)$ & LEA $\left(A_{\boldsymbol{i}}\right)$ \\
\hline CL1 & Diano d'Alba & 11.435 & 133.38 & 1.000 \\
CL2 & Grinzane Cavour & 2010 & 3.81 & 0.010 \\
CL3 & Neive & 4101 & 29.06 & 0.170 \\
CL4 & Nizza Monferrato & 17.632 & 97.71 & 0.410 \\
CL5 & Canelli & 15.906 & 62.72 & 0.430 \\
CL6 & Rosignano Monferrato & 6754 & 101.23 & 0.220 \\
\hline
\end{tabular}

\subsection{Results for the Moraine Amphitheatre of Ivrea}

In Table 7, the percentage values of population in early, temporary, and final times are shown. It has to be noticed that the time scale is arbitrary, so Figure 5a,b show only an asymptotic trend of each population. The historical series about the population dynamics are necessary to fix an actual time scale. Such evolution can be seen also in Figure 5.

Ivrea (CL1), Pavone Canavese (CL6) and Castellamonte (CL8) are the clusters with the highest number of residents, while Lessolo (CL2) and Moncrivello (CL5) have the lowest one. These two last clusters show the strongest increase of residents, in a standard condition (see the last column in Table 6), whereas Pavone Canavese and Castellamonte have a more or less accentuated decrease. Furthermore, the decrease in Ivrea is evident. This result may be determined by a geographical centrality of cluster that favors the people mobility towards the most peripheral clusters. In the first case (Figure 5a, Ivrea), a strong polarization of the dynamic populations can be observed. This is due to the fact that the number of inhabitants in Ivrea is much greater than in the other municipalities considered in the model (see below the case of CL4 (Bollengo). In the second case (Figure 5b), the trends of attractiveness have been investigated, excluding the cluster of Ivrea (CL1, see Table 8) from the multi-pole territorial system. The exclusion of CL1 favored a growth of population equal to $2 \%$ for the most part of the clusters system, except for Pavone Canavese (CL6) and Castellamonte (CL8) which conversely show a rather strong decline (Figure $5 b$ ). For these reasons and for our purposes, strictly connected to landscape economic attractiveness analyses, we consider the second picture more significant than the first one.

The dynamic model favors a territorial system of small urban centers; in the case of main clusters as Ivrea, Pavone Canavese, and Castellamonte, the model shows a decrease of population.

As shown in Tables 7 and 8, Moncrivello has initially a growth of population and then a fall, because of its moderate value of attractiveness, whereas Lessolo has a positive monotone behavior. The clusters of Bollengo and Borgofranco d'Ivrea are the most resilient because of the combined effect of population and attractiveness values. More specifically, it must be underlined that Bollengo is close to Ivrea even at its borders and therefore, the inclusion or exclusion of Ivrea modifies strongly the population forecasts. 


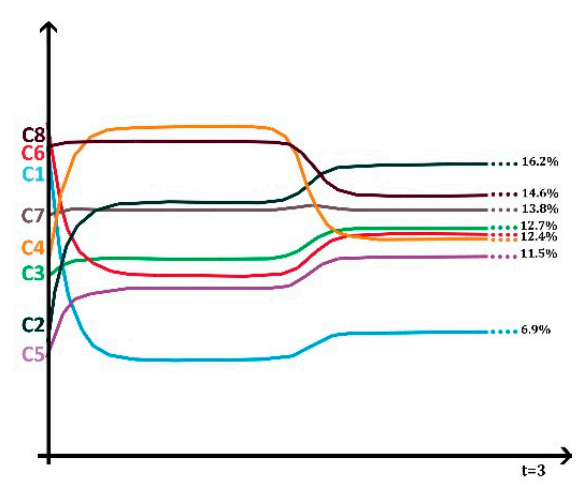

(a)

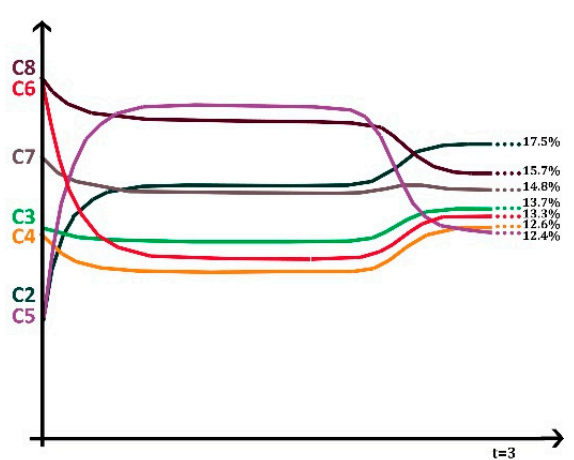

(b)

Figure 5. Simulation of the population mobility before (a) and after (b) the exclusion of the cluster of Ivrea from the MAI clusters system.

Table 7. Percentage distribution of the population dynamics in the MAI landscape as resulting from the complete integrated model.

\begin{tabular}{lcccc}
\hline \multirow{2}{*}{ Clusters } & \multicolumn{3}{c}{ \% Population } \\
\cline { 3 - 5 } & & Early Time & Transient Time & Final Time \\
\hline CL1 & Ivrea & 19.0 & 5.4 & 6.9 \\
CL2 & Lessolo & 6.3 & 14.2 & 16.2 \\
CL3 & Borgofranco 'Ivrea & 10.0 & 11.1 & 12.7 \\
CL4 & Bollengo & 9.9 & 9.4 & 11.8 \\
CL5 & Moncrivello & 5.4 & 18.4 & 11.5 \\
CL6 & Pavone Canavese & 18.8 & 10.1 & 12.4 \\
CL7 & Caluso & 13.5 & 13.8 & 13.8 \\
CL8 & Castellamonte & 17.2 & 17.6 & 14.6 \\
\hline
\end{tabular}

Table 8. Percentage distribution of the population dynamics in the MAI landscape as resulting from the integrated model (excluding Ivrea from the clusters system).

\begin{tabular}{lcccc}
\hline & Clusters & \multicolumn{3}{c}{ \% Population } \\
\cline { 3 - 5 } & & Early Time & Transient Time & Final Time \\
\hline CL2 & Lessolo & 7.7 & 15.8 & 17.5 \\
CL3 & Borgofranco & 12.4 & 11.7 & 13.7 \\
CL4 & Bollengo & 12.2 & 9.9 & 12.6 \\
CL5 & Moncrivello & 6.6 & 19.5 & 12.4 \\
CL6 & Pavone Canavese & 23.2 & 10.7 & 13.3 \\
CL7 & Caluso & 16.6 & 14.6 & 14.8 \\
CL8 & Castellamonte & 21.3 & 18.7 & 15.7 \\
\hline
\end{tabular}

\subsection{Results for the Vineyard Landscape of Langhe, Roero and Monferrato}

The dynamic model shows the dynamic trends of attractiveness coefficients about the six core zones in terms of percentage of people flows (Table 9).

Cluster 1, Diano D'Alba, starts with $11 \%$ of population and ends with $16 \%$, showing a maximum value (Figure 6). Cluster 2 Grinzane Cavour has a slight growth (1\%), presenting a maximum value.

Cluster 3, Neive is the one with the highest growth, equal to $18.4 \%$, because of the high LEA and SLEA indices and the low number of residents; the same is for cluster 6, Rosignano Monferrato, with a population growth of $10.7 \%$; it graphically does not show points of maximum or minimum.

On the other hand, Nizza Monferrato is one of the least resilient clusters because its population declines from $33.1 \%$ to $21.5 \%$. The dynamic model also predicted for the cluster of Canelli a loss of 
$13.8 \%$ of population. These predictions are correlated to the presence of industrial activities in both clusters that influence negatively their economic attractiveness as well as their adaptive capacity.

In fact, the clusters of Diano d'Alba (CL1), Nizza Monferrato (CL4), and Canelli (CL5) are resilient clusters, because of the combined effect between the high number of residents and LEA indices.

In the Figure 6, clusters Diano D'Alba (CL1) and Grinzane Cavour (CL2) show moderate overshoots due to the effect of the economic attractiveness. Conversely, Nizza Monferrato (CL4) shows a decrease to an undershoot. Further on, the logistic effect dominates and the populations accommodate themselves to the asymptotic value. Clusters of Neive (CL3), Canelli (CL5), and Rosignano (CL6) present a monotone behavior since attractiveness and resident threshold values have a combined effect and attractiveness does not dominate during the transient process. As it concerns cluster CL5, such a trend is due to the fact that it presents the highest number of residents of the territory so that the effect due to the resident thresholds value dominates the evolution.

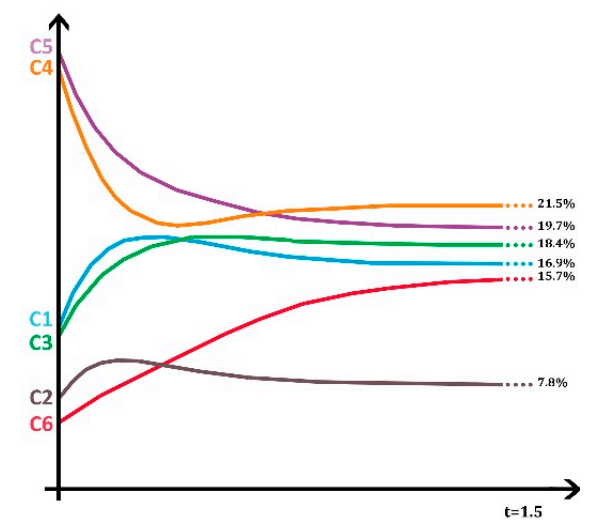

Figure 6. Simulation of the population mobility in the LRM clusters system.

Table 9. Percentage distribution of the population dynamics in the LRM landscape as resulting from the integrated model.

\begin{tabular}{lccc}
\hline \multirow{2}{*}{ Clusters } & \multicolumn{2}{c}{ \% Population } \\
\cline { 3 - 4 } & & Early Time & Final Time \\
\hline CL1 & Diano d'Alba & 11.2 & 16.9 \\
CL2 & Grinzane Cavour & 6.3 & 7.8 \\
CL3 & Neive & 10.8 & 18.4 \\
CL4 & Nizza Monferrato & 33.1 & 21.5 \\
CL5 & Canelli & 33.5 & 19.7 \\
CL6 & Rosignano Monferrato & 5.0 & 15.7 \\
\hline \multicolumn{2}{r}{ Note: } & In this clusters system there is not any transient time.
\end{tabular}

\section{Sensitivity Analysis}

Despite the several convergences of the obtained results, a sensitivity analysis has been performed to test the robustness of this model. This sensitivity analysis is based on the "one-at-a-time" approach. The OAT approach [41-43] is used to validate the reliability of the outputs delivered by landscape and territorial evaluations, such as in the case of systems of indicators and indices. Specifically, the OAT approach increases the performance of the system of indicators by varying the weight of a single indicator and maintaining the other indicators on their central values. In this way, the OAT approach examines the effects of the weights variation on final results [44].

In this application, the stability of results has been tested by varying the weights of the categories of landscape value and examining whether these changes modify LEA and SLEA indices. The one-at-a-time (OAT) approach [45] has been used meaning that the weight of one attribute at a time has been increased to 0.700 , whereas keeping the other weights equal to 0.100 . In this way, it is 
possible to observe the effects on final results (Table 10). A further scenario has also been considered by assuming the equal weights to the 4 categories.

Table 10. Determination of scenarios changing the weights of landscape indicators.

\begin{tabular}{|c|c|c|c|c|c|c|}
\hline \multirow[b]{2}{*}{ Macro-Indicators } & \multicolumn{6}{|c|}{ Scenarios } \\
\hline & $\begin{array}{l}\text { Original } \\
\text { Scenario }\end{array}$ & $\begin{array}{c}\text { Equal } \\
\text { Scenario }\end{array}$ & $\begin{array}{l}\text { Agriculture } \\
\text { Scenario }\end{array}$ & $\begin{array}{l}\text { Tourism } \\
\text { Scenario }\end{array}$ & $\begin{array}{c}\text { Real Estate } \\
\text { Scenario }\end{array}$ & $\begin{array}{l}\text { Forestry } \\
\text { Scenario }\end{array}$ \\
\hline Agriculture & 0.570 & 0.250 & 0.700 & 0.100 & 0.100 & 0.100 \\
\hline Tourism & 0.168 & 0.250 & 0.100 & 0.700 & 0.100 & 0.100 \\
\hline Real Estate & 0.075 & 0.250 & 0.100 & 0.100 & 0.700 & 0.100 \\
\hline Forestry & 0.187 & 0.250 & 0.100 & 0.100 & 0.100 & 0.700 \\
\hline
\end{tabular}

\subsection{Results for the MAI Landscape}

The results of the sensitivity analysis for the MAI landscape are reported respectively in Figure 7a,b. As it is possible to see, 6 scenarios have been generated having the original weight condition, the equal weight condition and other 4 situations in which one category is predominant. The results of the sensitivity analysis show a variability in the values (Table 11), which is mainly related to the tourism scenario, while in the other scenarios the number remains the same. This variation in the tourism scenario has to be attributed to the fact that tourism presences are mostly concentrated in the city of Ivrea, whereas the other clusters are represented by small centers. In this sense, it is possible to affirm that the landscape is constituted by a highly polycentric system where Ivrea predominates on the other centers. For this reason, when the tourism category assumes a very high importance in the calculation of LEA and SLEA indices, the values becomes very low for the majority of the clusters which have very low performance in terms of tourism, while a very high for the cluster of Ivrea. In the light of this explanation the results of the model can be considered acceptable, thus validating the calculations done.

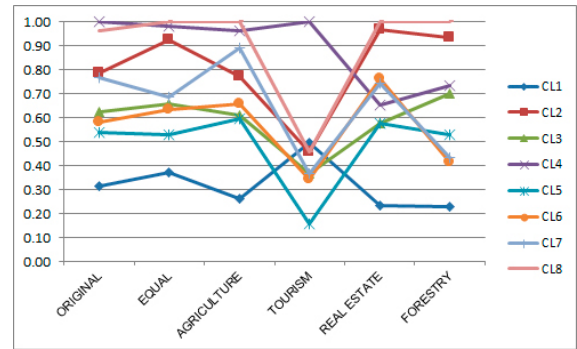

(a)

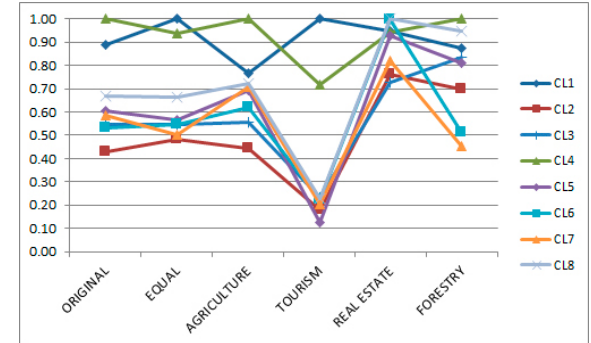

(b)

Figure 7. Results of sensitivity analysis for MAI landscape context for LEA (a) and SLEA (b) indices.

Table 11. Results of sensitivity analysis for LEA and SLEA indices of the MAI landscape.

\begin{tabular}{|c|c|c|c|c|c|c|c|c|c|c|c|c|}
\hline \multirow[t]{2}{*}{ Cluster } & \multicolumn{2}{|c|}{$\begin{array}{l}\text { Original } \\
\text { Scenario }\end{array}$} & \multicolumn{2}{|c|}{$\begin{array}{c}\text { Equal } \\
\text { Scenario }\end{array}$} & \multicolumn{2}{|c|}{$\begin{array}{l}\text { Agriculture } \\
\text { Scenario }\end{array}$} & \multicolumn{2}{|c|}{$\begin{array}{l}\text { Tourism } \\
\text { Scenario }\end{array}$} & \multicolumn{2}{|c|}{$\begin{array}{c}\text { Real Estate } \\
\text { Scenario }\end{array}$} & \multicolumn{2}{|c|}{$\begin{array}{l}\text { Forestry } \\
\text { Scenario }\end{array}$} \\
\hline & LEA & SLEA & LEA & SLEA & LEA & SLEA & LEA & SLEA & LEA & SLEA & LEA & SLEA \\
\hline CL1 & 0.316 & 0.888 & 0.373 & 1.000 & 0.263 & 0.769 & 0.495 & & 0.234 & & 0.228 & 0.875 \\
\hline CL2 & 0.785 & 0.430 & 0.924 & 0.483 & 0.775 & 0.441 & 0.457 & 0.180 & 0.969 & 0.763 & 0.935 & 0.699 \\
\hline CL3 & 0.625 & 0.545 & 0.659 & 0.548 & 0.611 & 0.554 & 0.368 & 0.231 & 0.579 & 0.726 & 0.702 & 0.836 \\
\hline CL4 & 1.000 & & 0.984 & & 0.961 & 1.000 & 1.000 & 0.720 & 0.653 & 0.941 & 0.732 & 1.000 \\
\hline CL5 & 0.540 & 0.605 & 0.528 & 0.566 & 0.596 & 0.695 & 0.156 & 0.126 & 0.576 & 0.929 & 0.529 & 0.810 \\
\hline CL6 & 0.583 & 0.529 & 0.632 & 0.548 & 0.657 & 0.621 & 0.342 & 0.224 & 0.763 & 0.997 & 0.413 & 0.512 \\
\hline CL7 & 0.766 & 0.586 & 0.689 & 0.503 & 0.891 & 0.709 & 0.368 & 0.203 & 0.743 & 0.818 & 0.435 & 0.454 \\
\hline CL8 & 0.962 & 0.668 & 1.000 & 0.663 & 1.000 & 0.723 & 0.457 & 0.228 & 1.000 & 1.000 & 1.000 & 0.948 \\
\hline
\end{tabular}




\subsection{Results for the LRM Landscape}

The results of both LEA and SLEA models show a very limited variability in Figure 8a,b. Moreover, it is interesting to notice that the LEA indices are not affected by a variance on the set of weights, thus continuing the validity of the outcomes (Table 12).

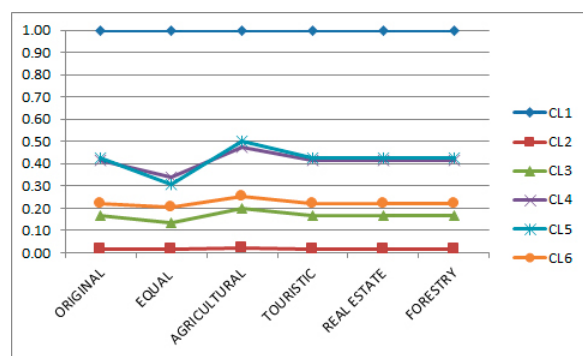

(a)

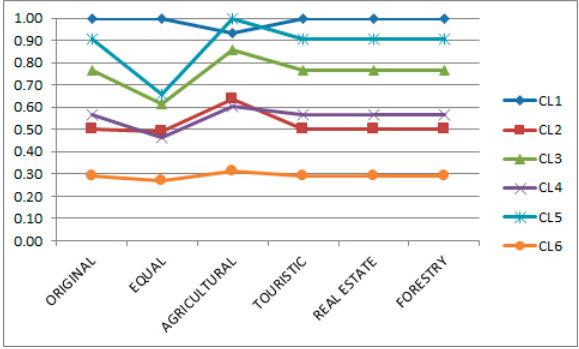

(b)

Figure 8. Results of sensitivity analysis for the six core zones of vineyard landscape for LEA (a) and SLEA (b) indices.

Table 12. Results of sensitivity analysis for LEA and SLEA indices of the LRM landscape.

\begin{tabular}{ccccccccccccc}
\hline \multirow{2}{*}{ Cluster } & \multicolumn{2}{c}{$\begin{array}{c}\text { Original } \\
\text { Scenario }\end{array}$} & \multicolumn{2}{c}{$\begin{array}{c}\text { Equal } \\
\text { Scenario }\end{array}$} & \multicolumn{2}{c}{$\begin{array}{c}\text { Agriculture } \\
\text { Scenario }\end{array}$} & \multicolumn{2}{c}{$\begin{array}{c}\text { Tourism } \\
\text { Scenario }\end{array}$} & \multicolumn{2}{c}{$\begin{array}{c}\text { Real Estate } \\
\text { Scenario }\end{array}$} & \multicolumn{2}{c}{$\begin{array}{c}\text { Forestry } \\
\text { Scenario }\end{array}$} \\
\cline { 2 - 14 } & LEA & SLEA & LEA & SLEA & LEA & SLEA & LEA & SLEA & LEA & SLEA & LEA & SLEA \\
\hline CL1 & 1.000 & 1.000 & 1.000 & 1.000 & 1.000 & 0.934 & 1.000 & 1.000 & 1.000 & 1.000 & 1.000 & 1.000 \\
CL2 & 0.014 & 0.500 & 0.014 & 0.493 & 0.020 & 0.634 & 0.014 & 0.500 & 0.014 & 0.500 & 0.014 & 0.500 \\
CL3 & 0.167 & 0.766 & 0.135 & 0.617 & 0.200 & 0.855 & 0.167 & 0.766 & 0.167 & 0.766 & 0.167 & 0.766 \\
CL4 & 0.413 & 0.564 & 0.340 & 0.464 & 0.470 & 0.602 & 0.413 & 0.564 & 0.413 & 0.564 & 0.413 & 0.564 \\
CL5 & 0.426 & 0.906 & 0.310 & 0.659 & 0.500 & 1.000 & 0.426 & 0.906 & 0.426 & 0.906 & 0.426 & 0.906 \\
CL6 & 0.220 & 0.290 & 0.207 & 0.272 & 0.250 & 0.312 & 0.220 & 0.290 & 0.220 & 0.290 & 0.220 & 0.290 \\
\hline
\end{tabular}

\section{Conclusions}

This paper described an innovative methodology based on an integrated approach for the evaluation of landscape. The combined employment of the system of landscape economic indicators and the dynamic model represents a promising framework to investigate and support the definition of landscape policies and scenarios in the decision-making process. The proposed indicators system is a useful approach for measuring the economic attractiveness of a landscape, and the versatile dynamic model is suitable for testing the importance of the landscape value, considering for instance the population movements influenced by attractiveness towards a specific area [12].

We have focused the research on two particularly attractive rural landscapes in Piedmont that are natural attraction poles, the Moraine Amphitheatre of Ivrea and the vineyard landscape of Langhe, Roero and Monferrato. An additional purpose was to develop a reliable tool for the decision-making process in the allocation of the resources and ecosystem services, which are important for human well-being [46].

Some future challenges have emerged for this research. Firstly, we will expand the evaluation to a wider area, including in the model the extra-systemic movements of people, especially regarding those from and towards the metropolitan city of Turin. Despite the sensitivity analysis performed to test the stability of this model, different procedures for the normalization of the LEA indices should be examined also considering the use of different set of weights based on real stakeholders values [47,48]. Secondly, the dynamic model will be further tested to better investigate the semi-quantitative character of the temporal dynamics, focusing on how to translate the number of iterations of this model into specific temporal units. This could be done by means of a comparison of the results of the model with the effects on the systems under investigation over a period of time that is known. Lastly, the use of the proposed system of indicators and indices will be applied to those landscapes that need an 
intervention, such as for the inner areas affected by depopulation or that develop difficulty, due to the presence of major centers. In this sense, the LEA index may aid the decision makers in the definition of mitigation and compensation measures, thus increasing the economic attractiveness of critical areas.

Author Contributions: All authors equally contributed to the article.

Funding: This research received no external funding.

Conflicts of Interest: The authors declare no conflict of interest. The funders had no role in the design of the study; in the collection, analyses, or interpretation of data; in the writing of the manuscript, or in the decision to publish the results.

\section{References}

1. Council of Europe. European Landscape Convention. US/ICOMOS Sci. J. 2000, 2, 88-92.

2. Cassatella, C.; Peano, A. Landscape Indicators: Assessing and Monitoring Landscape Quality; Springer: Berlin, Germany, 2011; ISBN 9789400703650.

3. Bottero, M.; Caprioli, C.; Berta, M.; Mondini, G.; Oppio, A.; Stanghellini, S.; Bottero, M.; Abastante, F. Urban problems and patterns of change: The analysis of downgraded industrial area in Turin. Values Funct. Future Cities. Green Energy Technol. 2019, in press.

4. van der Heide, C.M.; Heijman, W.J.M. The Economic Value of Landscapes; Routledge: London, UK, 2013; ISBN 9780203076378.

5. Marangon, F.; Tempesta, T. Proposta di indicatori economici per la valutazione del paesaggio. Estimo Territ. 2008, 5, 40-55.

6. Bottero, M. Assessing the economic aspects of landscape. In Landscape Indicators: Assessing and Monitoring Landscape Quality; Springer: Berlin, Germany, 2011; pp. 167-192. ISBN 9789400703650.

7. Tempesta, T.; Thiene, M. Percezione e Valore del Paesaggio; FrancoAngeli: Milan, Italy, 2006; ISBN 9788846479136.

8. Pagiola, S.; Arcenas, A.; Platais, G. Can Payments for Environmental Services Help Reduce Poverty? An Exploration of the Issues and the Evidence to Date from Latin America. World Dev. 2005, 33, 237-253. [CrossRef]

9. Pearce, D.W.; Turner, R.K. Economia Delle Risorse Naturali e Dell'ambiente; Il Mulino: Ft. Lauderdale, FL, USA, 1991; ISBN 9788815032850.

10. Monaco, R.; Rabino, G.A. A Stochastic Treatment of a Dynamic Model for An Interacting Cities System. In Mathematical Modelling in Science and Technology; Elsevier: Amsterdam, The Netherlands, 1984.

11. Assumma, V.; Bottero, M.; Monaco, R. Landscape Economic Value for Territorial Scenarios of Change: An Application for the Unesco Site of Langhe, Roero and Monferrato. Procedia Soc. Behav. Sci. 2016, 223, 549-554. [CrossRef]

12. Assumma, V.; Bottero, M.; Monaco, R.; Soares, A.J. An integrated evaluation model for shaping future resilient scenarios in multi-pole territorial systems. Environ. Territ. Model. Plan. Des. 2018, 4, 17-24.

13. Brunetta, G.; Salizzoni, E.; Bottero, M.; Monaco, R.; Assumma, V. Measuring resilience for territorial enhancement: An experimentation in Trentino. Valori e Valutazioni 2018, 20, 69-78.

14. Assumma, V.; Bottero, M.; Monaco, R.; Soares, A.J. An integrated evaluation methodology to measure ecological and economic landscape states for territorial transformation scenarios: An application in Piedmont (Italy). Ecol. Indic. 2019, 105, 156-165. [CrossRef]

15. Piorr, H.P. Environmental policy, agri-environmental indicators and landscape indicators. Agric. Ecosyst. Environ. 2003, 17-33. [CrossRef]

16. Costanza, R.; Folke, C. Nature's Services: Societal Dependence on Natural Ecosystems. In Nature's Services: Societal Dependence on Natural Ecosystems; Island Press: Washington, DC, USA, 1997; ISBN 1-55963-476-6.

17. Hanley, N.; Wright, R.E.; Adamowicz, V.I.C. Using Choice Experiments to Value the Environment. Environ. Resour. Econ. 1998, 11, 413-428. [CrossRef]

18. Tagliafierro, C.; Longo, A.; Van Eetvelde, V.; Antrop, M.; Hutchinson, W.G. Landscape economic valuation by integrating landscape ecology into landscape economics. Environ. Sci. Policy 2013, 32, 26-36. [CrossRef]

19. Tagliafierro, C.; Boeri, M.; Longo, A.; Hutchinson, W.G. Stated preference methods and landscape ecology indicators: An example of transdisciplinarity in landscape economic valuation. Ecol. Econ. 2016, 127, 11-22. [CrossRef] 
20. Bottero, M.; Mondini, G.; Datola, G. Decision-making tools for urban regeneration processes: from Stakeholders Analysis to Stated Preference Methods. Tema J. L. Use Mobil. Environ. 2017, 10, 193-212.

21. Tyrväinen, L. The amenity value of the urban forest: an application of the hedonic pricing method. Landsc. Urban Plan. 1997, 37, 211-222. [CrossRef]

22. Bottero, M.; Bravi, M.; Dell'Anna, F.; Mondini, G. Valuing buildings energy efficiency through Hedonic Prices Method: Are spatial effects relevant? Valori e Valutazioni 2018, 21, 27-39.

23. Tempesta, T. People's preferences and landscape evaluation in Italy: A review. New Medit 2014, 1, 50-59.

24. Gómez-Sal, A.; Belmontes, J.A.; Nicolau, J.M. Assessing landscape values: A proposal for a multidimensional conceptual model. Ecol. Model. 2003, 168, 319-341. [CrossRef]

25. Saaty, T.L. The Analytic Hierarchy Process: Planning, Priority Setting, Resource Allocation; McGraw-Hill International Book Co.: New York, NY, USA; London, UK, 1980; ISBN 0070543712.

26. Bottero, M.; Mondini, G. Valutazione e Sostenibilità. Piani, Programmi, Progetti; Ambiente valutazioni e sostenibilità; CELID: Torino, Italy, 2009; ISBN 9788876618451.

27. OCDE Environmental Indicators. Towards Sustainable Development; Organisation for Economic Co-operation and Development (OECD): Paris, France, 2001.

28. Gottero, E.; Cassatella, C. Landscape indicators for rural development policies. Application of a core set in the case study of Piedmont Region. Environ. Impact Assess. Rev. 2017, 65, 75-85. [CrossRef]

29. Schaller, L.; Targetti, S.; Villanueva, A.J.; Zasada, I.; Kantelhardt, J.; Arriaza, M.; Bal, T.; Fedrigotti, V.B.; Giray, F.H.; Häfner, K.; et al. Agricultural landscapes, ecosystem services and regional competitiveness-Assessing drivers and mechanisms in nine European case study areas. Land Use Policy 2018, 76, 735-745. [CrossRef]

30. Terkenli, T.S. Landscapes of Tourism. In The Wiley Blackwell Companion to Tourism; Lew, A.A., Hall, C.M., Williams, A.M., Eds.; John Wiley \& Sons, Ltd.: Oxford, UK, 2014; ISBN 9781118474488.

31. Tyrväinen, L.; Miettinen, A. Property prices and urban forest amenities. J. Environ. Econ. Manage. 2000, 39, 205-223. [CrossRef]

32. Bell, S.; Morse, S. Sustainability Indicators: Measuring the Immeasurable? 2nd Ed. ed; Routledge: Abingdon, UK, 2012; ISBN 9781849772723.

33. Singh, R.K.; Murty, H.R.; Gupta, S.K.; Dikshit, A.K. An overview of sustainability assessment methodologies. Ecol. Indic. 2012, 9, 189-212. [CrossRef]

34. Assumma, V.; Bottero, M.; Monaco, R.; Mondini, G. Assessing the Landscape Value: An Integrated Approach to Measure the Attractiveness and Pressures of the Vineyard Landscape of Piedmont (Italy); Springer: Berlin, Germany, 2019; Volume 101, ISBN 9783319921013.

35. Monaco, R. Introduzione ai Modelli Matematici Nelle Scienze Territoriali/Roberto Monaco, Giorgia Servente; Quaderni di matematica per le scienze applicate 2; Nuova, Ed.; Celid: Torino, Italy, 2011; ISBN 978-88-7661-927-4.

36. Brunetta, G.; Monaco, R.; Salizzoni, E.; Salvarani, F. Integrating landscape in regional development: A multidisciplinary approach to evaluation in Trentino planning policies, Italy. Land Use Policy 2018, 77, 613-626. [CrossRef]

37. Murray, J.D. Mathematical Biology: I. an Introduction; Springer: Berlin, Germany, 2002; ISBN 0387952233.

38. Smith, H.L. Monotone Dynamical Systems: An Introduction to the Theory of Competitive and Cooperative Systems; American Mathematical Society: Providence, RI, USA, 1995; ISBN 082180393X.

39. Committee, W.H. The Vineyard Landscapes of Piedmont: Langhe-Roero and Monferrato; Official document for evaluating the inscription into the UNESCO; UNESCO: Paris, France, 2014.

40. Regione Piemonte. Schede degli Ambiti di Paesaggio; Regione Piemonte: Piazza Castello, Torino, 2015.

41. Daniel, C. One-at-a-Time Plans. J. Am. Stat. Assoc. 1973, 68, 353-360. [CrossRef]

42. Harrison, P.; Bobbins, K.; Culwick, C.; Humby, T.-L.; Mantia, L.; Todes, A.; Weakley, D.; Adegun, O.; Bickford, G.; Bing, G.; et al. Urban Resilience Thinking for Municipalities; Gauteng City-Region Observatory: Johannesburg, South Africa; University of the Witwatersrand: Johannesburg, South Africa, 2014.

43. Bottero, M.; Datola, G.; Monaco, R. Exploring the Resilience of Urban Systems Using Fuzzy Cognitive Maps; Springer: Berlin, Germany, 2017; pp. 338-353.

44. Pasqualini, V.; Oberti, P.; Vigetta, S.; Olivier, R.; Christophe, P.; Cannac, M.; Ferrat, L. A GIS-Based Multicriteria Evaluation for Aiding Risk Management Pinus pinaster Ait. Forests: A Case Study in Corsican Island, Western Mediterranean Region. Environ. Manag. 2011, 48, 38-56. [CrossRef] [PubMed] 
45. Bottero, M.; Ferretti, V.; Mondini, G. Calculating composite indicators for sustainability. In Proceedings of the Lecture Notes in Computer Science, Banff, AB, Canada, 22-25 June 2015; Springer: Berlin, Germany, 2015; pp. 20-35.

46. Scolozzi, R.; Morri, E.; Santolini, R. Delphi-based change assessment in ecosystem service values to support strategic spatial planning in Italian landscapes. Ecol. Indic. 2012, 21, 134-144. [CrossRef]

47. Fitzsimons, J.; Pearson, C.J.; Lawson, C.; Hill, M.J. Evaluation of land-use planning in greenbelts based on intrinsic characteristics and stakeholder values. Landsc. Urban Plan. 2012, 106, 23-34. [CrossRef]

48. Store, R.; Karjalainen, E.; Haara, A.; Leskinen, P.; Nivala, V. Producing a sensitivity assessment method for visual forest landscapes. Landsc. Urban Plan. 2015, 144, 128-141. [CrossRef]

(C) 2019 by the authors. Licensee MDPI, Basel, Switzerland. This article is an open access article distributed under the terms and conditions of the Creative Commons Attribution (CC BY) license (http://creativecommons.org/licenses/by/4.0/). 